\title{
EDUCATION FOR ADJUSTMENT TO AGEING
}

By Clark Tibbitts, B.S., Director of the Institute for Human Adjustment, University of Michigan.

IN both Britain and the United States older people are increasing. The proportion of persons 60 years of age and over in the United States will reach 17 per cent by 1980 compared to 6 per cent in 1900 . In the British Isles 20 per cent will be in the old age group by 1979 as against about 5 per cent in 19or. Numerically, there are 6 million such persons in Britain and 14 million in America at the present time.

These changes are even more striking when they are considered in parallel with the tremendous reduction in manpower required to produce the goods and services needed in the two countries. In a hundred years the productivity of the American worker has increased five-fold while the weekly hours of work have dropped from about $7^{\circ}$ to around 40. The figures for Britain are becoming equally impressive.

Adult ageing creates serious problems for the individual and for society, some of the more difficult ones arising from the paradoxical situation described above. Employers with labour surpluses have tended to discriminate against the older in both layoff and hiring. Retircd workers, including wives and widows without adequate means of support, have increased even faster than the population. Two-thirds of the aged require financial assistance. Ten million Americans are placed in the position of feeling dependent upon others and are still unable to meet normal needs. Society is now having to struggle with the problem of providing even minimum support. Both the Rowntree document and the American Stettinius report insist that neither country can long afford to support retired populations of great size.

Another phase of the same problem is that there are now large groups of persons, quite able in body and mind, in both countries who are deprived of feelings of usefulness to themselves and to others and who, consequently, are unhappy and, often, bitter. Relatively few have been able to develop satisfactory substitute activities. While there has been much urging of hobbies, such interests seldom provide opportunity for financial return nor do they enable the individual to feel that he is making a contribution. The effect of this discontentedness upon society is not 
yet as clearcut as is that of having to provide financial support but it is becoming more real as the number of idle persons in later maturity increases.

There are other problems. The retired worker or housewife tends to be removed from all sorts of activity and responsibility even to the point of finding their grown children willing to manage their lives for them. Thus, instead of finding a value placed upon their long years of experience they often discover that nothing they have to offer is desired. Many become completely devoid of recognition for their worth as human beings.

The effects of the tendency to remove older people from participation in any type of affairs are aggravated further by the dispersion of their children and the death of spouse, relatives, and close friends. Older people, then, find it more and more difficult to obtain the response from intimate associations of the kind to which they have been accustomed since babyhood. So, too, most of them have been too busy during their productive years to broaden their interests, and communities afford little along this line for them.

Finding suitable living arrangements represents another difficulty. Most wish to retain the responsibility for management of their own homes and lives and they realise the dangers inherent in living with married children. Independence is not compatible, however, with the need for care and protection when illness or infirmity appears. Older people need smaller quarters devoid of hazardous conditions. Large-scale housing has had the undesirable characteristic of removing older people from the surroundings in which they have their remaining friends and interests, and, also, of offering little more than a vegetative existence.

Finally, ageing in adults is characterised by slowing of bodily and mental functions, increased incidence of chronic illness, and the appearance of fears and anxieties. The individual needs guidance in the matter of handling his physical and psychological disabilities and in avoiding the consequences of frustrations and losses.

Some people age successfully. Winston Churchill and Herbert Hoover are examples. They are financially secure, they enjoy unusually good health, they have families and friends, they know they will receive sympathetic care when they are very old and infirm. Perhaps most important of all, both have been allowed to continue their lifetime interests into old age and have been sought by their countries as experienced leaders and counsellors. Everyone, however, is acquainted with older people who are not well adjusted, who are not finding with Rabbi Ben Ezra that

"The best is yet to be, The last of life, for which the first was made." 


\section{Assistance through Education}

A year ago the University of Michigan acted upon the thinking of some of its staff members regarding adjustment in old age. Through its Extension Service it announced an experimental twelve-week course on ageing and living for adults. Later the course was extended to the Detroit metropolis.

Decision to offer the course was based on two principles which have now become fairly well established.

I. Growing old is a lifelong process of development and atrophy and requires individual behaviour adjustment as each new stage is reached. The earlier assumption that major changes in the organism and in mental processes were restricted to the first part of life is no longer held.

2. Successful living at any age requires preparation. Elementary school programmes are adjusted with great care, recognising that the child and youth must be inducted into each new phase of development. Adult education in America as in Britain is based on the recognition that preparation for successive stages must be continued throughout life. The adjusted individual is the one who knows himself and the conditions of living.

The course was intended to cover all phases of life in eight broad fields and to include practical suggestions to aid in individual adjustment.

Biological Ageing. In the first lecture the pathologist pointed out that ageing is natural and that it is common to all species: It consists of evolutionary changes as organs, cell tissues, and functions develop from the ovum and of parallel involutionary changes which actually begin prior to birth. Metabolism falls markedly soon after birth, motor capacities decline in the twenties, reproduction ceases in the forties or fifties. Evolution predominates in the first part of life; involution, or decline and deterioration, in the latter part. Death is a natural consequence that would occur even in the absence of disease. Death, moreover, is necessary to the preservation of man-the old must disappear to make way for new and more nearly perfect generations.

The lecturer recognised that all deplore the wrinkles, the missing teeth, the loss of virility and vitality, the decline in memory for recent events, and the more deliberate thinking that comes with ageing but he demonstrated with singular success that these are indicative of maturity, that it is not undignified to possess such traits, and that they may be signs of a full life.

Psychological Changes. The philosophy of ageing was well established when the psychologist reviewed the evidence for satisfactory mental activity well into the seventh and eighth decades. It may be Nature's purpose to bring the biological functions to maturity in middle age and, 
thus, free the individual for community participation and guidance of others during the latter half of life. Continued exercise of the psychological processes and the maintenance of human relationships, said the psychologist, appear to offer the best guarantee of satisfaction in old age. Arbitrary retirement ages are in conflict with existing evidence regarding the differential rate of functional decline. Everyone will be happier and financially more secure when this fact is recognised.

Maintenance of Physical and Mental Health. Atrophy of tissues and organs, appearance of chronic disease, and onset of infirmity are inevitable. So, too, are changes in family structure, loss of friends, modified capacity for work, and ultimate retirement from all strenuous activity. The medical physician told how the wise individual can forestall many health problems, live in comparative comfort, and, indeed, prolong life. The psychiatrist identified the situations that are likely to cause frustrations and suggested ways in which older people may handle them in order to avoid much of the unhappiness and anxiety found among older people.

Living Arrangements. Where, with whom, and how to live was identified earlier as one of the more serious problems of most older people and of their children and, hence, of the entire community. There was ample justification for including a consideration of the mental hygiene, sociological, functional, financial, and health factors in successful living arrangements. This topic was presented by a social worker who possessed rich experience in helping older people meet their problems.

Creative Activities. Need for leisure time activities is a natural consequence of American and British life with reduced working hours and of the years added to millions of lives through greater longevity. The course undertook to describe a good many activities which would serve one or more of several purposes: occupying time, using individual capacities and special abilities, providing a sense of creativeness, affording social contacts, and giving a feeling of usefulness. The topics covered included recreation and education through motion pictures, art, drama, reading, music and the radio; creativeness through painting, writing, weaving, ceramics, metal work and gardening; and community participation through reading and listening and through actual engagement in community affairs. This phase of the course was conducted by a group of experts in recreation and handerafts.

Religion. Research reveals that older people often turn toward religion to find a philosophy for old age and, hence, solace for their dissatisfactions. Fortunate, indeed, was the selection of a great religious scholar for this presentation. Tracing the history of religion and the shortcomings of religious groups, the lecturer provided a broad formula for individual religious behaviour in keeping with the principles of ageing and usefulness through activity outlined in earlier sessions. 
Social and Economic Security. Financial security, meaning food, shelter, clothing, provision for medical attention and care during periods of helplessness, and opportunity to participate in the life of the community has been seen as a basic problem of older people and of society as well. One lecture period was given to a presentation of the types of benefits or pensions available through both public and private sources. Equally important was the discussion of the industrialised urbanisation of society which has led to the appearance of large numbers of unoccupied older pcople and to the problems of housing, activities, and financial support for them. The needs of older populations were seen in relation to those of other dependent groups, and in relation to the needs of all people and to the productive capacity of the nation.

Legal Problems. For the immediate benefit of the students, an outstanding professor of law discussed several problems having to do with making wills, passing property, inheritance taxes, establishment of trusts, and administration of estates.

\section{Some Results}

The first course drew fifty people; the second had an enrolment of ninety. It has been interesting and gratifying to discover the students taking more objective attitudes toward ageing, giving more attention to their own physical well-being, seeking ways to exercise their mental capacities, and practically demanding opportunity for self-expression and social participation.

One demonstrable result of the first course was the formation of a Senior Citizens Group with a programme of lectures on cultural and political topics, dramatics, and recreation. Old people who have been withdrawn for years are eating group suppers, making new friendships, and playing at sports they had never dreamed of.

The course is not a panacea. It will not supplant the services of individual counsellors, social workers, physicians, or other professional persons. It does appear, however, that the series of lectures may become a factor in promoting good mental health among older people and among those with the foresight to prepare for old age.

Neither will it substitute for the attitudes, commodities, services and opportunities that society must supply. A well-adjusted population of older people will come about when we recognise such persons as individuals with normal needs-wanting useful employment consistent with their individual capacities, entitled to living arrangements suited to their conditions and interests, needing adequate medical care, and requiring opportunity for self-expression and social participation. It is obvious that cducation has a service to perform with reference to the whole population as well as for the old people alone. 